\title{
The Practical Significances and Challenges of Assets Disclosure and Registration Law in Combating Illicit Enrichment Crime in Ethiopia
}

\author{
Diriba Adugna Tulu \\ Attorney General Office of Oromia Regional State, Addis Ababa, Ethiopia
}

Email address:

Adugnatulu10@gmail.com

\section{To cite this article:}

Diriba Adugna Tulu. The Practical Significances and Challenges of Assets Disclosure and Registration Law in Combating Illicit Enrichment Crime in Ethiopia. International Journal of Education, Culture and Society. Vol. 5, No. 3, 2020, pp. 34-44. doi: 10.11648/j.ijecs.20200503.11

Received: January 27, 2020; Accepted: February 25, 2020; Published: May 28, 2020

\begin{abstract}
A well-designed and structured ADR system can be used as a strong tool to combat corruption effectively and eventually lead to successful conviction of illicit enrichment crime. The main objective of this study is to identify the practical significances and challenges of implementing the ADR law in combating illicit enrichment in Ethiopia and forwards the recommendations for the identified issues. In order to achieve the research aims, the author employed the combination of doctrinal and empirical legal research approach. Accordingly, this article analyzed both primary and secondary data sources. Then, the data were analyzed and interpreted to draw conclusions. Based up on the research findings, it argues that the Ethiopian ADR law has not comprehensively designed to combat illicit enrichment crime. Besides, it was poorly implemented in fighting illicit enrichment crime in Ethiopia. Thus, this article recommends different measures to be taken into account by the government, law enforcement and FEACC so as to enhance the effective implementation of the ADR law in combating illicit enrichment in Ethiopia.
\end{abstract}

Keywords: Corruption, Crime, Assets Disclosure and Registration, Illicit Enrichment, Asset Disclosure, Asset Declarations

\section{Introduction}

Corruption constitutes one of the most serious problems that the world is facing today [1]. This phenomenon is found in all countries but it is in the developing world that its effects are most destructive [1]. In this regard, Ethiopia is not exceptional to these issues [2].

In order to curb corruption problems, various international and regional anticorruption instruments and strategies are adopted and came in to force with the intention of preventing and combating corruption in a coordinated manner. Among other anti-corruption strategies, Asset Disclosure and Registration (ADR) scheme have been recognized internationally and regionally by anti-corruption instruments as a means of ensuring integrity in public service [3]. For example, Article 8 of United Nations Convention Against Corruption (UNCAC) addresses in general terms the need for states parties to ensure probity in public office. Specifically, Article 8(5) requires States Parties to establish systems that require public officials to declare, inter alia, "their outside activities, employment, investments, assets and substantial gifts or benefits" [3]. Among the regional anti-corruption instruments, Article 7(1) of the African Union Convention on Preventing and Combating Corruption (AUCPCC) also provides a similar requirement for public officials to declare their assets before, during, and after serving in public office [3]. These Conventions accept the significant role of assets disclosure by public official's plays in combating corruption crimes and related offences in the public service.

Ethiopia is a party to most international and regional anticorruption instruments. It has signed and ratified UNCAC [4] and the AUCPCC [5]. To ensure its commitments under those conventions, the government of Ethiopia has promulgated Assets Disclosure and Registration (ADR) Procl. No.668/2010 in April 2010 and illicit enrichment crime under Article 21 of Corruption Crimes Procl. No.881/2015 [6]. Thus, the Ethiopian ADR law has been envisaged to avoid possible conflict of interest and prevention of corruption crimes as well as to assist in the detection, investigation, and prosecution of underlying act of illicit enrichment of the 
public officials' who have acquired wealth corruptly [7].

Even though Ethiopia has enacted ADR law and other anticorruption laws, it is important to note that corruption acts persist as a pressing issue in Ethiopia. From the Corruption Perception Index (CPI) data released by TI, there is CPI data that gives a score and ranks of the countries in the world including Ethiopia, with data for Ethiopia from 2016-2018, as captured below.

Table 1. Ethiopia's Score and Ranking TI's CPI from 2016-2018.

\begin{tabular}{lll}
\hline Year & Score & Rank \\
\hline 2016 & $34 / 100$ & $108 / 176$ \\
2017 & $35 / 100$ & $107 / 180$ \\
2018 & $34 / 100$ & $114 / 180$ \\
\hline
\end{tabular}

Source: TI/www.transparency.org/cpi (May, 2019)

From the above table, corruption had been remaining as a serious problem in Ethiopia. Thus, any score below 50 on the CPI indicates serious levels of public sector corruption. Moreover, according to World Justice Project Rule of Law on 2019 Index, Ethiopia was ranked $118^{\text {th }}$ out of 126 countries with a score of 0.39 [9], where any score below 0.40 on the rule of law index indicates weaker adherence to the rule of law. In addition, one study also indicates that, "small number of illicit enrichment cases were investigated and prosecuted at Federal level" [10]. He also noted that, "the federal government was far behind to prosecute those who are enriching themselves suddenly in unlawful manner". Hence, all of the above data and research indicates that corruption crime is the major problems in Ethiopia. In contrast, Alemayehu noted that, "the effectiveness of the Ethiopian government in combating corruption crimes has been increased and level of corruption perception index decreased at steady level post the enactment of the ADR law and increased cleanness of corruption crimes in the country" [11]. Therefore, the key question to be answered in this article is that whether Ethiopian ADR law has been adequately designed to battle illicit enrichment crime or not.

Against this background, this Article is intended to examine the practical significances and challenges of implementing the ADR law in combating illicit enrichment in Ethiopia. To do this, the study employed the combination of doctrinal and empirical legal research approach in utilizing both primary and secondary data sources. Thus, the former was used to in-depth analysis of the laws in relation to the subject matter of the research, where as the later was used to examine the practical application of the law in society. Accordingly, relevant international instruments, Ethiopian laws, books, articles, cases, reports, relating to the matters were reviewed along with key informants interview selected purposively from FEACC (Federal Ethics and AntiCorruption Commission), FAG (Federal Attorney General), and FPC (Federal Police Commission).

The structure of this article goes in the following manner. Following this first section, the second section of the discussion tries to provide the general concepts of the ADR system. The third section identifies the practical significances and challenges faced under the existing Ethiopian ADR law in combating illicit enrichment crime. As usual, the article ends up with conclusion and recommendations on ways forward.

\section{The General Conceptual Framework of Assets Disclosure and Registration System}

\subsection{Conceptualizing Assets Disclosure and Registration System}

ADR has no commonly accepted and single definition. Since the term reflects the social, political, economical and cultural contexts in which it is being operated, its contents may vary from country to country and even within a country from time to time based on the changes in government anticorruption policy. Despite this, there are attempts to define the term. For instance, Rossi, Laura and Tammar defined the terms as, "a mechanism by which a public official must periodically submit information about his or her income, assets, liabilities, and/or interests"[12]. ADR also referred to as asset disclosure, income and asset declarations, wealth reporting, and interest declarations. Further, the terms refer to "the entire process of disclosing assets, and interests, from the blank form to submission, verification, and sanctioning" [13].

ADR frameworks are not new. Its systems began to evolve into modern form after the Second World War [14]. In the 1960s, due to corruption scandals in places like the United States of America, Hong Kong and the Netherlands', governments changed its direction to ADR system as one mechanism of prevention of corruption [15]. Following the USA, the UK House of Commons introduced the register of interests in 1974, while other European countries followed suit with laws of their own in the early 1980s [16]. "The global number of ADR laws spiked dramatically in the 1990s as the cold war ended and many other countries in the former Soviet Bloc adopted new constitutions along with the newlyindependent nation-states of Africa" [14]. As Vargas and Schlutz indicated, the ADR regulation has greatly expanded across all the country since 1996s to 2012s [17].

In spite of growth both in the number of countries with ADR laws and in the role that the disclosure plays in international efforts to fight corruption, it is worthy to note that ADR provisions have not always translated into effective systems [17]. Thus, its implementation is often leaving a large gap between the system "in law" and "in practice" in different countries [17].

\subsection{The Purpose of Assets Disclosure and Registration System}

The importance of the ADR system in fighting corruption is increasing day by day, through monitoring the development and changes of the public officials' wealth. As Burdescu et al rightly put, "ADR can play two important 
roles within broader anti-corruption efforts: prevention, and law enforcement" [14]. In the preventive function, "the ADR system seeks to prevent corruption through increasing the sense of responsibility and accountability to public officials, where they are required to disclose their assets and benefits periodically subject to sanctions in case of abstain to comply with it"[18]. Besides, the law enforcement role of the ADR is to assists the investigation and prosecution of corruption crimes as a source of information which will be easier to reveal the cover off the required information or data related the public official [17].

\subsection{Models of Assets Disclosure and Registration System}

Many considerations should be taken into account in designing the ADR system. As Burdescu et al noted that, "the scope of implementation, making balance between the public right to know and the right of privacy of individuals, how to control the monitoring of compliance and verification, budgetary and the qualified personnel are crucial to run the ADR system" [14]. Besides, designing according to objectives is also another major consideration on how to know which model can meet the size of corruption [18].

Ironically, a model of ADR is determined depending on the legal framework and objectives of ADR systems. Thus, three main models worldwide have been identified [13]. These are:"the illicit enrichment, conflict of interest and the mixed model. Illicit Enrichment Model is primarily focus on the prevention, detection, investigation or prosecution of illicit enrichment"[18]. In this system, declarations are planned to capture information that will enable the tracking of an official's wealth to detect any unusual assets or income not attributable to salary or other legitimate source [13]. Conflict of Interest Model is a sort of warning or caution to conflict of interest. It offers assistance to avoid situations which may lead to such conflict and to ensure that the filler is not subjected to accusations or suspicions of bias or corruption [18]. The third model is a combination of illicit enrichment and conflict of interest models. That is to say, it has the preventive role side-by-side with the law enforcement of detection of illicit enrichment. Thus, it aims to reduce the conflict of interest and detecting the wealth of the public officials, join the investigation and assist prosecution of corruption crimes.

\subsection{Principles for an Effective Assets Disclosure and Registration System}

As highlighted above, recognizing the potential of the ADR system in combating corruption, the 2003 UNCAC agreement stipulated that all signatories should establish mechanisms to compel public officials' to report "to appropriate authorities (...) their outside activities, employment, investments, assets and substantial gifts of benefits" [3]. Despite this, there are, as yet, no specific international standards detailing how the ADR regimes are best designed, implemented and monitored [18]. Over the last decade, however, an emerging consensus has identified several core principles for the establishment of effective ADR mechanisms [20]. Accordingly, consistent with international standards and the preventive measures for governments outlined in Chapter III of the UNCAC, TI identified the following core principles for an effective and legally based ADR system based on its previous publications in this area [21]. These principles are: (a) Clear Objectives; (b) Coverage of Public Officials; (c) Content and Comprehensiveness of Declarations; (d) Filling Frequency and Submission of Declarations; (e) Verification Mechanisms; (f) Public Access; and (g) Enforcement and Sanction.

\section{The Role of Assets Disclosure and Registration Law in Combating Illicit Enrichment Crime in Ethiopia}

Despite its infancy, no doubt that the ADR system might be plays a significant roles and made positive progress in the effective administration of corruption crimes in Ethiopia. Practically, there are certain potentials of the ADR scheme in combating illicit enrichment crime. Some of the evident significant are discussed below.

\subsection{Potentials of Assets Disclosure and Registration Law in the Detection, Investigation and Prosecution of Illicit Enrichment Crime}

It is undisputable that illicit enrichment is difficult crime to prove, and it is undetectable by traditional investigation mechanisms. Further, being a consensual crime committed by powerful individuals, there are serious problems in obtaining concrete evidence against corrupt officials. It is only the abnormal or unusual increases or changes on the wealth indicate an occurrence of suspicious act of illicit enrichment [19]. Due to such difficulty of detecting and prosecuting illicit enrichment, many jurisdictions including Ethiopia choose to implement the ADR system as an alternative mechanism to combat illicit enrichment by monitoring and flagging significant changes in appointees, elected persons and public servants wealth that cannot be explained by legitimate income [13]. For instance, the ADR proclamation authorizes "the FEACC to report any evidence or any reasonable suspicions of criminal activity by appointees, elected persons and public servants to the law enforcement, upon verifying the declarations" [7]. This provision is crucial because it indicates the relevance of declarations in initiating the process of investigating and prosecuting appointees, elected persons and public servants for corruption crimes.

Despite the fact that the ADR endeavor is its infancy, it is contributing its lion share to the effectiveness of law enforcement activities in Ethiopia [22]. During my field work, I asked the key informants to describe the practical significance of the ADR scheme in the detection, investigation and prosecution of illicit enrichment crime in Ethiopia. One of the key informants from the ADR directorate told this researcher that, "information provided in the ADR form of appointees, elected persons and public 
servants has been used by police and prosecutor as an additional investigatory tool during investigations of illicit enrichment crime" [23]. This can be substantiated by report of FEACC. Accordingly, as annual report produced by the FEACC indicated, "165 of the registered assets forms of appointees, elected persons and public servants have already been used by the justice bodies for investigation purposes" [24]. In addition, other key informants from the police and prosecutor reveal that, "ADR will accelerate the investigation of illicit enrichment allegation and assist in easing the evidence gathering process in the efforts that are underway to investigate and prosecute it" [25]. Further, they said that, "ADR scheme will serve as supportive or corroborative evidence to file illicit enrichment charges as well as in the litigation of it in the court" [25]. This is evident from the cases of Oromia Ethics and Anti-Corruption Commission Prosecutor v. Zelalem Jemane et al, [26] and Federal Attorney Prosecutor v. Zenaye Tamena, [27] which the public prosecutor has produced asset declared form by defendants pursuant to ADR proclamation as one supportive evidence under the list of documentary evidence.

In general, as it can be understandable from the above interviewees, reports and cases, ADR scheme form filled by appointees, elected persons and public servants may be used as cause for an investigation; as assistance in an investigation, and as evidence in the prosecution of illicit enrichment crime.

\subsection{The Challenges Facing Assets Disclosure and Registration System in Combating Illicit Enrichment Crime in Ethiopia}

As we already stated above, ADR system has made some significant roles and positive progress in combating illicit enrichment so as to assist in the effective administration of corruption crimes. However, its effective implementation is not free from challenges. Thus, there are certain challenges that have affected the ADR system in combating illicit enrichment. According to this study, some of these challenges are discussed below.

\subsubsection{Assets Disclosure and the Right to Privacy}

The right to privacy can be regarded as main challenges to the ADR system. There is a debate and contention between the rights to privacy and the public interest in access to information regarding an appointee, elected person and public servant assets [13]. Accordingly, here, there are two arguments for and against public disclosure of information submitted by appointees, elected persons and public servants among scholars. Those authors that favor disclosure of registered assets hold the view that, "public access to registered assets by an appointee, elected person and a public servant is associated with lower levels of perceived corruption";[28] "reinforce public scrutiny; increase deterrent effect, and promote greater effectiveness of ADR system so that its objectives to prevent and combat corruption will be achieved in advance" [13]. Some other authors in the second view, on the other hand, claim that, "a public disclosure is the infringement of the right to privacy" [29]. There is no doubt that the privacy of an appointee, elected person and a public servant is infringed as their private lifestyles and business are made public and subjected to public scrutiny.

In Ethiopia, the above mentioned hot debate between the need for public disclosure and the right to privacy may also poses a problem from the reading of Article 12(1) of the proclamation [7]. Though the practice is different (we shall see the detail on this issue under section 3.2.6), the law requires all registered assets of an appointees, elected persons and public servants has to be open to the public. During my field work, the respondents were asked whether the ADR law considered as a challenge and infringement of the right to privacy of an appointees, elected persons and the public servants. Thus, according to interview held with the key informants, "ADR law does not contradict with the right to privacy of an appointee, elected person and the public servant" $[25,30]$. The respondents further said that,

"as per the FDRE Constitution, the right to privacy is subject to limitation only in compelling circumstances and in accordance with specific laws whose purposes shall be the safeguarding of national security or public peace, the prevention of crimes or the protection of health, public morality or the rights and freedoms of others" [31].

According to this provision, preventing and exposing unexplained wealth of appointees, elected persons and the public servants are serious and legitimate public interests which may restrict the right to privacy. In Ethiopia, it is possible to surmise that there is strong constitutional justification to impose disclosure of an appointee, elected person and public servant assets for the public. As it is stated above, however, they seek to strike a balance between the infringement of privacy and the need to prevent corruption crimes in general and illicit enrichment crime specifically.

\subsubsection{Human Rights and Constitutional Challenges to Illicit Enrichment Crime}

Human rights and constitutional challenges often arise in relation to the criminalization and prosecution of illicit enrichment. It has been challenged for violating the constitutional presumption of innocence as it supposedly shifts the onus of proof from the state to the accused, who is required to prove his or her innocence [12].

In Ethiopia, the presumption of innocence is a fundamental principle of human rights and criminal justice, as in other legal systems. The FDRE constitution guarantees the presumption of innocence during criminal trial. It is provided for under Article 20(3) of the FDRE constitution, which states that, "during proceedings accused persons have the right to be presumed innocent until proven guilty according to law and not to be compelled to testify against themselves" [31]. This right is not only founded in the FDRE Constitution but also in various international instruments which are integral parts of Ethiopian's law envisage the standard of proof beyond a reasonable doubt in criminal cases $[31,32]$.

Under Article 13 of the ADR proclamation, it is provided that, 
"any asset of an appointee, an elected person or a public servant not registered in accordance with this proclamation shall, in the absence of proof to the contrary, be considered as an unexplained property for the purpose of applying the provisions of Article 419(2) of the criminal code (as amended by Corruption Crimes Proclamation No.881/2015, Article 21)".

Accordingly, the presumption made for non-registration of assets of appointees, elected persons or public servants will be treated as an offence of illicit enrichment. Thus, this presumption of non-registration of assets and fake registration of assets allows for an investigation initiated under the Corruption Crimes Proclamation No.881/2015 and the defendant can be punished under the same proclamation if he found guilty. The burden will be shifted to the shoulder of the defendant that he or she needs to prove that the excessive property has been obtained through legal means. Upon an unsatisfactory explanation during the court proceeding, "the defendant shall be punished with simple imprisonment and fine, or in serious cases, with rigorous imprisonment not exceeding five years and fine not exceeding Birr five thousand" [6].

It is worth noting that, Article 20(3) of the FDRE constitution does not provides an exception to the presumption of innocence and permits reverse onus provisions in certain circumstances. In precise terms, it does not provide for how and when the presumption of innocence could be subject to limitation. As a result of this loophole in the constitution, there is a contested and unresolved debate among legal scholars about whether illicit enrichment in Ethiopian anti-corruption law violates human rights and constitutional values enshrined in the FDRE Constitution [33]. Accordingly, some scholars consider "the shifting of the burden of proof as some sort of infraction against the principles of presumption of innocence enshrined in the FDRE constitution and its constitutional values" [34]. They argued on the ground that the reversal of the burden of proof violates the defendant's right to due process. On the contrary, other author like Meskele, disagrees with the conclusion that, "illicit enrichment violates human rights, and considers presumption of innocence as not absolute principle" [35]. She argued that, "illicit enrichment crime and their reverse onus clauses are compatible with the presumption of innocence envisaged under Article 20(3) of the FDRE constitution".

In the opinion of the author of this article, the second argument is more tenable. It is important to stress that, the use of presumption would be necessary to combat corruption for several reasons [36]. First, the fact that a defendant has accumulated wealth does not prove corruption. Nevertheless, the presumption can be a best tool to battle corruption and likely to result in more successful prosecutions for corruption and be a deterrent. Secondly, since corruptions are consensual crimes committed by powerful individuals, there are serious difficulties in terms of evidence gathering. Thirdly, the source of wealth and how the defendants got it is largely within the knowledge of the defendants and difficult for the prosecution to establish. Fourth, even where direct evidence of the actus reusis obtained, the mens rea may be hard to prove where a defendant claims that they though the payment was a gift [37].

Akin to Ethiopia, in countries like Hong Kong that do not have an express exception to the principles of presumption of innocence in their legislation, illicit enrichment provisions have been found still to be constitutional. For instance, in the case of Attorney General v. Hui Kin Hong [38], the court ruled that,

"shifting of burden of proof on a defendant would not be in breach of the presumption of innocence since it is no more than a necessary part of preserving the balance of fairness between the accused and the prosecutor in matters of evidence."

Furthermore, the court of appeal of Hong Kong found that, "the reverse onus provision under section 10(1)(a) was justifiable in light of the nature of the offence and the inherent difficulty of obtaining adequate evidence, and thus was consistent with the Bill of Rights of Hong Kong" [39].

If interpreted in this manner, the conclusion is that the offence of illicit enrichment under Ethiopian anti-corruption law does not violate the human rights and other constitutional values granted to the accused person in the FDRE Constitution.

\subsubsection{Absence of Lifestyle Checks}

Lifestyle checks are examines into whether the lifestyle of an appointees, elected persons and the public servants is manifestly out of proportion to his or her known income [12]. Thus, for detecting illicit enrichment, one assesses the lifestyle of these persons by adding up all assets he or she owns [21]. They are undertaken by inquiring the assets, activities, and expenditures of appointees, elected persons and public servants. This involves an examination of the financial activities of the public official or public servants, which may extend to a valuation of immovable property and vehicles, verification of income, stocks, nature of schools attended by children, loan and tax payments, travel, extravagant parties, family background checks, and other expenditures [12, 18]. If the income mismatches the life style, there is at least a suspicion that this an appointees, elected persons and the public servants has disguise source of income.

According to my key informants, "inquires into illicit enrichment are impeded by the lack of mechanisms for monitoring the financial affairs of an appointees, elected persons and the public servants who exhibit extravagant lifestyle" $[25,40]$. The respondents further said that, "thought lifestyle checks are more likely than other means of verification to help detection of illicit enrichment; there is no practice in Ethiopia due to the fact that it requires resources intensive to undertaking" [25, 40]. Therefore, Ethiopia needs to use lifestyle check as a source and an aid to detect, investigate and prosecute illicit enrichment.

\subsubsection{Use of Third Parties}

Investigating and prosecuting illicit enrichment is 
complicated further by the use of third parties and front entities to camouflage the true ownership of assets [12]. The participants of interview raised their concern with regard to the use of third parties as one main challenge to investigate and prosecute illicit enrichment.

"Corrupt officials do not deposit large sums illicitly obtained in their personal bank accounts, nor do they hold expensive homes or cars realized from corruption in their own name. Rather, they open bank accounts in the name of associates or a corporation, or find other ways to overshadow the ill-gotten assets from public' view" [25, 40].

In such a case, third parties may assert ownership over the assets, who may able to demonstrate legal ownership of the assets and claim that they are not the target of an investigation. [12] In these scenarios, identifying the assets held in the name of associates and third parties will be extremely difficult for investigators. Further, the problem is extremely worsened where the assets are layered through a complex web of corporate vehicles in which the corrupt official has no identifiable interest [12].

Compounded to the above raised challenges, the ADR proclamation does not require any appointees, elected persons or the public servants to declare the assets and income of their children above the age of 18 , close relatives and other third parties. This means assets which have been amassed by appointees, elected persons or public servants during their tenure will be transferred to businesses run by their close relatives and children above 18 years of age. These assets then washed by infusion into the banking system. This idea was also up held by Meskele, for her, "in a society like Ethiopia, the relationship among members of extended families is very tight" [35]. In such a case, the possibilities of hide and the transfer of illegally obtained property to close relatives and other persons are likely to be increase. This issue in turn results, cases of illicit enrichment invisible and hard to detect, investigate and prosecute.

\subsubsection{Capacity Constraints of Assets Disclosure and Registration Expert}

The other issue with regard to the challenges of ADR system in combating illicit enrichment is a problem relating to the skill and competence of the ADR professionals. A qualified and skilled staffs who are trained to guidance to filers, and data management technologies in order to assist in the submission, handling and verifying of the declaration are key to detect illicit enrichment [13]. Further, ADR system enforcement experts must have basic skills in areas where illicit enrichment crime is committed. Besides, they should have basic skills and tools to scrutinize declarations, detect irregularities, and identify signs that could indicate improper conduct [14].

As indicated in the 2018/2019 nine month annual performance report, for instance, the FEACC raised the concern that, "it is facing the shortage of skilled and experienced expertise in the areas of receiving, verifying and maintaining the ADR scheme" $[23,25,41]$. At FEACC, out of the 313 total employees, only 25 number of staffs members are engaging currently on asset disclosure and registration work in the directorate, which are very insignificant compared to the wideness of the scope and the number of registered assets of an appointees, elected persons and the public servants $[25,41]$. The above indicated report gets support from the all interviewees. The interviewees mentioned that,

"the ADR directorate of FEACC is currently facing capacity constraints such as: lack of sufficient number of skilled and experienced force in areas of verification, absence of dedicated personnel, and lack of sufficient training in all the areas of the ADR law implementation" [23, 25].

By way of conclusion, the existence of such capacity limitations has made thing very difficult for the FEACC in its fighting against illicit enrichment through the ADR schemes. And, this may in turn render the ADR system goals largely ineffective.

\subsubsection{Lack of Accessibility of Registered Information}

The asset declarations that are submitted by appointees, elected persons or public servants should be publically available. Despite the long debate concerning privacy rights vs. public disclosure, there are defensible reasons for making asset declarations publicly available. For further information with regard to privacy right vs. asset disclosure, read section 3.2.1 of this research.

Interestingly, public disclosure can serve as a preventive measure, as the declarations of appointees, elected persons or public servants will be under the scrutiny of the public at large. Moreover, it will increase the possibility of irregular asset declarations being detected by the investigation agency or any other investigative journalist or member of the public. Therefore, the public disclosure of registered information is considered defensible, as the public interest overrides personal interest (privacy right).

Article 12 of the ADR Proclamation states that, "all information regarding the registered information assets shall be open to the public and any person who wishes to access information regarding the registration of assets may apply in writing". The implementation of this provision by the FEACC, however, "is currently facing difficulty since the registered information is not made available to the public at large" [23, 25].

As annual reports produced by the FEACC indicated some of the registered information has already been used by the FEACC itself and other justice bodies for investigation purposes. However, the public has no easy access yet to the registered information nine years after the commencement of the ADR system in the Ethiopia [24]. During my field work, many of my key informants told me that,

"lack of clarity with regard to answer the questions; what information to be disclosed? When and in what mechanisms to be accessed under article 12(1) of the ADR proclamation, compounded with absence of regulation to implement the ADR proclamation are believed to be one of the principal reasons for curtailing an easy access to the registered information" [23, 25, 41]. 
This problem is intensified by the lack of modern technological resource to handle the activities of the ADR system. With a view to organizing and publishing registered information in modern technology, various efforts have also been made to implement electronic filing and data management software system for the ADR scheme in collaboration with local company called "Africom PLC" and its Indian counterpart [41]. Nevertheless, the work was not yet completed until the writing of this article due to several reasons [41]. Thus, registered information by any appointees, elected persons and public servants is not yet available to the public online in Ethiopia.

In general, the success story with respect to the ADR system in Ethiopia has so far been limited to registration only. Therefore, the real objectives of the ADR law in combating illicit enrichment crime in the public functions through this scheme has meaningless unless the registered information is made available to the public at large.

\subsubsection{Absence of Rigorous Verification of Registered Assets}

Verification of declared asset is an extremely crucial element of the ADR systems, and also one of the hardest parameters to implement [14]. Importantly, the verification system should allow the detection of illicit enrichment situations by comparing declaration, access time or against other information such as tax declarations, and real-estate registrations. The absence of a verification mechanism means allegations of corruption crimes; in particular, those concerning illicit enrichment are not investigated. This in turn results the public loss of confidence on anti-corruption agency and other justice bodies, and allows perpetrators to walk free. Therefore, if the content of the declarations are not verified, it is difficult to use the ADR system as a means for detecting and combating illicit enrichment crime.

From its inception to until the time of writing this article, the ADR directorate of FEACC has so far registered the assets of nearly 200,000 elected persons, political appointees and public servants [23, 41]. Nevertheless, registering the assets of those individuals who have the obligation to register their assets is not the end of the story. Rather, the proclamation requires the FEACC to undertake verification on the information submitted by the elected persons, political appointees and public servants [7].

According to my key informants, "the ADR directorate of FEACC verified only 23 of the nearly 200,000 declarations submitted by the elected persons, political appointees and public servants" $[24,41]$. An interviewee in relation to policy selection of already registered assets reiterated that, "a target approach which prioritizes the declarations of certain public officials whose responsibilities make them more prone to corruption has not applicable during undertaking of verification" [23, 24, 40]. Rather, random sample verification is the only approach applicable in practice [40]. In these regard, using random select, out of 23 verified declarations, only one detected red flag or indicated discrepancy and referred to FPC investigation bureau for further investigations [40].
In the opinion of the author, though random approach verification can create a deterrent effect throughout the entire pool of those individuals who have the obligation to register their assets, it will be less effective due to the fact that it may leave out an appointee, elected persons and public servants who have high-ranking positions or positions that more prone to corruption. By taking into considerations of the political, economic and social context of Ethiopia, a combination of the above mentioned approaches of verification are recommendable.

In light of these rough figures of verification, it seems difficult to conclude that verification of the accuracy of declarations is properly implemented by FEACC. Regrettably, here, the FEACC has so far lagged behind to undertake verification. An in-depth interview with key informants was conducted to understand the reason behind lack of robust verification. The interviewee mentions that,

"lack of adequate man power in the ADR directorate of the FEACC; lack of experience and skill on assets verification; absence of political commitment on part of the FEACC and the government; and absence of technological resources that undertakes the activities related to verification are attributed to the failure" [23, 40, 41].

This raises indeed the question, whether the ADR system in Ethiopia is rather a huge accumulation of paperwork for the mere purpose of window-dressing, than worth the effort. In precise terms, ADR system will only be successful if verification are reliably assure; otherwise, the tool remains empty ritual. The writer of this article, in a personal opinion come to suggest that the FEACC need to undertake rigorous and in depth verification of the already registered assets so as to attain the very purpose of the ADR law in combating illicit enrichment crime.

\subsubsection{Problems of Determining the Current Market Value of Registered Assets in Monetary Figures}

The legal framework of the ADR law could be challenged by the form of declaration [16]. The Ethiopian ADR form generally request any appointee, elected persons or public servants to provide the market value of the assets [42]. Nevertheless, how to express the market value of assets may raise a number of practical challenges in the identifying illicit enrichment crime.

In Ethiopia, current practices show that, "any appointee, elected person or public servant tend to determine the value of their wealth and assets based on their own beliefs rather than on current market value; therefore, the accuracy of the wealth declared is called into question" [41]. Some studies reveal also that, "providing the market value for real estate or land is challenging, as the value of these assets is in continuous flux and, in most cases, subjective" [13]. On the other hand, according to the interview held with my key informants, "the market value might also not be the most helpful for identifying illicit enrichment, as it is a subjective assessment made by any appointee, elected person or public servant" $[25,40]$.

Hence, the current form leaves room for manipulation and 
artificial increase in the price of the property. In fact, the FEACC has been granted the mandate to verify the information submitted where there is sufficient ground to suspect that the information is false, incomplete and inaccurate [7]. But, the verification process provided under the proclamation by itself does not guarantee the submission of accurate and real market value of property. In these scenarios, any appointee, elected person or public servant can use certain transaction to conceal illicitly obtained assets and other financial expenditures under this gap.

\subsubsection{Lack of Political Commitment and Willingness of the Government}

In all effort to implement the ADR system successfully, the commitment and willingness of the government is pivotal, as experience shows in other countries. Some author argues that, "lack of political will is a common characteristic of countries where corruption is rampant like Ethiopia" [43]. Further, some suggested also that, "political power in most poor countries is seen as the main and quick gateway to wealth" [44]. Hence, the ADR law is bound to fail in the absence of political will, as there will be no commitment by government to ensure the successful implementation of the law.

The key informants of my study those actually experienced with the process demonstrate that, "the lack of political will on the part of the government is one of the major obstacles to effective implementation of the ADR law in combating illicit enrichment crime in Ethiopia" [23, 25, 40]. According to my informants, this lack of political will exhibits itself on the following grounds.

"Firstly, since its adoption nine years ago, Council of Minister is not yet issued regulation to implement the ADR proclamation. Legal researchers often show that most laws fail to achieve the intended goals due to the absence of subsidiary laws. Secondly, the absence of punishment for defaulting an appointee, elected persons and public servants which in turn result non- deterrence effect on that official illicitly obtained assets. Thirdly, lack of accessibility of registered information's for public at large. Lastly, absence of robust verification of already registered information, compounded with lack of experience and sufficient numbers of skilled force as the work is new in the country" $[23,25,40]$.

In the opinion of the author, overall, the absence of political will in the implementation of the ADR law results in a lack of commitment to the enforcement of corruption laws in general and illicit enrichment crime specifically, and the punishment of corruption offenders. Even if every other aspect is put in place, without political will, the fight against illicit enrichment crime through the ADR system will remain futile in Ethiopia. This partly shows why corruption has persisted in the midst of varied ant-corruption legislation and institutions in Ethiopia.

\subsubsection{Lack of Enforcement for Non-Compliance of Assets Disclosure and Registration Law}

Unarguably, failure to comply with the ADR law by any appointee, elected persons and public servants entails administrative liability in the form of a fine and criminal punishment in Ethiopia. Though Ethiopia's ADR law recognizes the imposition of penalty on those persons who lately register his or her assets, fails to disclose his or her assets, and intentionally submits incorrect disclosure; [7] the implementation and enforcement of sanctions have been, and still are challenges in law and in practice.

Initially, ADR law fails to specify authority to sanction an appointees, elected persons and public servants who fillings lately their assets. Hereunder, it is important to understand that lack of clarity with regard to authority to sanction late registration of assets is a major issue which may hinder the effectiveness of the ADR system in combating corruption. This gap in law put those persons obliged to register their assets above the law and encourages a culture of impunity to thrive unchecked. Whilst some the appointee, elected persons and public servants submit their assets regularly, others do not submit at all, thus rendering the ADR system ineffective. Indeed, "in practice, there is no statistics on the implementation of the penalty prescribed in the ADR proclamation with regard to an appointee, elected persons and public servants who lately register their assets, fails to disclose their assets, and intentionally submits incorrect disclosure" $[23,25,30,40]$. Thus, both the ADR law and practices are vague in this regard.

In nutshell, in Ethiopia, the ADR law in relation to imposition of penalty upon an appointee, elected persons and public servants who failed to observe it remains paper tiger. In other words, without punishment for breach of ADR law, the law becomes merely political propaganda. Thus, unpunished violators of the ADR law encourage further corruption crimes, which in turn lead to its widespread or systemic, and eventually to its being accepted as inevitable. Therefore, Ethiopia needs to be effectively implementing the ADR law with regard to sanction and enforcement element so as to achieve its objectives to combat illicit enrichment crime.

\section{Conclusion and Recommendations}

This article has discussed the ADR law as an anticorruption tool. Corruption exists in every society; it is apparently exceptional in Africa. According to TI, Ethiopia is perceived to be one of the most corrupt countries in Africa.

In order to curb corruption, among other laws and strategies, the government of Ethiopia has promulgated the ADR law. Though the practice is different, the Ethiopian ADR law has been designed to avoid possible conflict of interest and prevention of corruption crimes as well as to assist in the detection, investigation, and prosecution of underlying act of possession of unexplained property of public officials who have acquired wealth corruptly.

This article is aimed at examining the adequacy, practical significances and challenges of the ADR law in combating illicit enrichment crime in Ethiopia. To achieve this purpose, a researcher employed a combination of doctrinal and empirical legal approaches. Accordingly, the researcher has analyzed the laws and collected data through interviews with 
expert from FEACC, FAG, and FPC. Then, the data were analyzed and interpreted to draw conclusions. Based up on the research findings, the major challenges that are negatively hindering the ADR law in effectively combating illicit enrichment in Ethiopia are: ADR law vis-a- vis right to privacy; human rights and constitutional challenges to illicit enrichment crime; absence of lifestyle checks; use of third parties; capacity constraints of the ADR expert; lack of accessibility of registered information; absence of rigorous verification of registered assets; lack of regulation to enforce the ADR law; problems of determining the current market value of registered assets in monetary figures; lack of political commitment and willingness of the government; and lack of enforcement for non-compliance of the ADR law. The findings of this research may serve as an input for better implementation of the ADR law in combating illicit enrichment crime and stepping stone for conducting such kind of study in the future.

On the basis of the aforementioned conclusion, my recommendation includes:

i. Ethiopia should hardly work on the primary focus of illicit enrichment purpose of the ADR system so as to prosecute corrupt officials.

ii. Article 13 of the ADR proclamation state that "any asset of an appointee, an elected person or a public servant not registered in accordance with this proclamation shall, in the absence of proof to the contrary, be considered as an unexplained property". Understandably, this is intended to facilitate effective prosecution of illicit enrichment crime. However, Article 20(3) of the FDRE constitution does not provides an exception to the presumption of innocence and permits reverse onus provisions in certain circumstances. This standard is not stipulated in the international human rights conventions. It is clear that shifting the burden of proof will minimize the accused's ability to his or her case and violates his or her right to presumption of innocence guaranteed under international instruments. In order to create conformity with international human rights and anticorruption instruments, the government should address this shortcoming through enabling accused to properly defend his case.

iii. The FEACC is unable to effectively handle and verify assets so many forms early in its life. Failing this, declarations have no deterrent effect, making illicit enrichment less unattractive and severely weakening the ADR framework. So, the FEACC should undertake rigorous and in depth verification of the already registered assets so as to combat illicit enrichment crime.

iv. As to accessibility of declared information, the law should clearly specify what information to be disclosed and the mechanisms to be accessed it. The FEACC should publish the registered assets of the public officials and civil servants, as well as the names of officials who do not comply with the ADR law, on their webpage and in a gazette that has high readership.

v. The government should use lifestyle check as a standard of verification approach and an aid to detect, investigate and prosecute illicit enrichment crime.

vi. The legislature or FEACC should issue law or specific guidelines which would allow the public officials and civil servants to determine the monetary value of their assets in monetary figures. If this occurs, declarations will do a better job of showing how wealthy public officials are and of revealing illicit enrichment crime.

vii. There should be application of sanctions for nonsubmission, late submission and false declaration. Authority to sanctions late registration of assets should be explicitly identified and penalty attached to it should also be severe. Law enforcement bodies need to show a track record of investigated cases with regard to failure to comply with the ADR law and should regularly report on case statistics to the public.

viii. Since there is no sufficient political will and commitment to promote the ADR regime in Ethiopia, the government should demonstrate political will and commitment.

ix. The FEACC and law enforcement bodies should provide adequate training for its employees concerning the purposes of the ADR scheme in combating corruption crimes and its remedies for the breach of the ADR law.

\section{References}

[1] Okechukwu I. Eme, I. Samuel, \& Ezenwafor E. C. (2017). African Anti-Corruption Agencies: Challenges and Prospects, Spring Management Studies and Economic Systems (MSES), 3(4), pp. 225-243.

[2] This can be evidenced from the TI Corruption Perception Index. Retrieved from www.transparency.org/cpi

[3] Inter-American Convention Against Corruption (IACAC), Mar. 29, 1996, 35 I. L. M. 724, Article 3; see African Union Convention on Preventing and Combating Corruption (AUCPCC), July 11, 2003, 43 I. L. M. 5, Article7, para 1; see also United Nations Convention Against Corruption (UNCAC) (2003), Article8(5).

[4] Ethiopia signed the Convention on 10 December 2003 and ratified it on 26 November 2007. Retrieved from https://www.unodc.org/documents/treaties/UNCAC/CountryV isitFinalReports/2015_10_14_Ethiopia_Final_County_Report. pdf.

[5] The Convention was signed by Ethiopia on 1 June 2004 and ratified on 18 September 2007.

[6] Corruption Crimes Proclamation, No. 881/2015, Negarit Gazeta, $21^{\text {st }}$ Year No.36, Addis Ababa, $3^{\text {rd }}$ April, 2015, Article 21.

[7] Assets Disclosure and Registration Proclamation No.668/2010, Negarit Gazeta, $16^{\text {th }}$ Year No. 18, Addis Ababa $12^{\text {th }}$ April, 2010, Preamble and Article 13. 
[8] TI, Corruption Perceptions Index. Retrieved from https://www.transparency.org/research/cpi.

[9] World Justice Project on the Rule of Law Index.(2018-2019). Retrieved from https://worldjusticeproject.org/sites/default/files/documents/W JP-ROLI-2019-Single\%20Page\%20View-Reduced 0.pdf.

[10] Negash, B. (2016). The Effectiveness of Anticorruption Institutions in Implementing International Anticorruption Instruments: The case of the Federal Ethics and Anticorruption Commission of Ethiopia, (Unpublished MA thesis, AAU).

[11] Alemayehu, B. (2015). A Study of the Role of Assets Disclosure and Registration Law Proclamation. No 668/2010 in Reducing Corruption: The Case of FEACC, (Unpublished MA thesis, AAU).

[12] Muzila, L., Morales, M., Mathias, M., and Berger, T. (2012). On the Take: Criminalizing Illicit Enrichment to Fight Corruption, (Washington, DC: World Bank).

[13] Rossi, Ivana M., Laura Pop, and Tammar Berger (2017). Getting the Full Picture on the Public Officials: A How to Guide for Effective Financial Disclosure. Stolen Asset Recovery (StAR) Series. Washington, DC: WB.

[14] Burdescu, R. Reid, GJ, Gilman, Stuart., and Trapnel, S (2009). Income and Asset Declarations: Tools and Trade-Offs. Washington DC: World Bank.

[15] WB \& UNODC. (2009). Asset and Income Declaration Guide Concept Note.

[16] OECD. (2011). Fighting Corruption in Eastern Europe and Central Asia Asset Declarations for Public Officials: A Tool to Prevent Corruption Paris' (OECD Publishing).

[17] Gustavo A. Vargas \& David S. (2016). Opening Public Officials Coffers: A Quantitative Analysis of the Impact of Financial Disclosure Regulation on National Corruption Levels, Eur J Crim Policy Res, pp. 439-475.

[18] Barnes, DW., Berger, Tammar., Burdescu, Ruxandra., Gilman, Stuart., Habershon, Alexandra M., Recancesca., Reid, Gary J., Trapnell, Stephanie E. (2012). Public Office, Private Interests: Accountability through Income and Asset Disclosure. Washington DC: World Bank.

[19] Mohannad, Zainal., andFauzin. (2016). The Law on the Illicit Enrichment Crime and Financial Disclosure in Jordan: Issue of Effectiveness and Enforceability, Vol. 2, No. 5 The Journal of Social Sciences Research, pp.100-105.

[20] Jenkins, M. (2015). Income and Asset Disclosure Topic Guide Compiled by the Anti-Corruption Helpdesk, Transparency International.

[21] TI. (2015). Asset Declarations in Morocco: Illicit Enrichment and Conflicts On of Public Officials.

[22] FEACC, $1^{\text {st }}$ Round (2003-2004 E. C). (2005). ADR Performance Report, Addis Ababa.

[23] Interview with AndualemTamene, Senior assets verification expert and Team leaders of Asset Disclosure and Registration Directorate at the FEACC, Done at his Office, 7 June, 2019.

[24] Federal Ethics and Anti-Corruption Nine Month Performance Report, 2018/2019 (FEACC Nine Month Performance Report, 2018/2019), p. 18.

[25] Interview with Woldemikael Fitora, Deputy Director of
Corruption Crimes Investigation Directorate at FPC, Done at his Office, 7 June, 2019; Interview with Zelalem Fekadu, Principal public Prosecutor and Prosecution Corruption Crime of Illicit Enrichment and Money Laundry coordination at the FAG, Done at his Office, 12 June, 2019; Interview with BekaluTamene, A Senior Public Prosecutor and Prosecution Corruption Crime of Abuse of Power Coordination Office Coordinator at the FAG, Done at his Office 12 June, 2019.

[26] Oromia Ethics and Anti-Corruption Commission Prosecutor v. Zelalem Jemane et al, Oromia Special Zone Surrounding Finfinne High Court, Judgment, Criminal File No.14761, [28/03/2010 E.C].

[27] Federal Attorney Prosecutor v. Zenaye Tamena, Federal High Court, Judgment, Criminal File No. 163956, [10/02/2009 E.C].

[28] Mukherjee, J and Gokcekus, O. (2006). Officials Asset Declaration Laws: Do They Prevent Corruption? (Transparency International Global Corruption Report), pp. 325-328.

[29] Messick, R. (2009). Income and Assets Declarations: Issues to Consider in Developing a Disclosure Regime 1.

[30] Interview with MeronAnemow, Public Prosecutor at the FAG, Done at her Office, 22 August, 2019 \& Interview with Indale Tsagaye, Public Prosecutor at the FAG, Done at his Office, 22 August, 2019.

[31] The Federal Democratic Republic of Ethiopia Constitution, Proclamation No. 1 of 1995, Article 26 (3).

[32] Universal Declaration of Human Rights, (10 December 1948, 217 A(III), Article 11(1); International Covenants on Civil and Political Rights, (16 December 1966, United Nations, Treaty Series, Vol. 999), Article 14(2); African Charter on Human and People's Rights, Art.7(1)(b); African Charter on The Rights and Welfare of the Child, Article 17(c) (i); Convention on the Rights of the Child, Article 40(2)(b)(i); UN Human Rights Committee (2007), General Comment No. 32.

[33] The Criminal Code of the Federal Democratic Republic of Ethiopia, Proclamation No.414/2004, NegaritGazeta, No., Year, $9^{\text {th }}$ of May, 2005, Article 419, (Corruption Crimes proclamation, Article 21).

[34] Assefa, S. K. (2012). The principle of the presumption of Innocence and its Challenges in the Ethiopian Criminal Process, Vol.6 No.2 Mizan Law Review, pp. 274-310.

[35] Meskele, M. T. (2012). The Legal Framework of Illicit Enrichment in Ethiopian Anti Corruption Law (Unpublished Master thesis, at the Faculty of Law, University of the Western Cape).

[36] Kofele-Kale, N. (2012). Combating Economic Crimes: Balancing Competing Rights and Interests in Prosecuting the Crime of Illicit Enrichment, (Oxford: UK, First Published by Routledge Research in Transnational Crime and Criminal Law).

[37] Wilsher, D. (2006). Inexplicable Wealth and Illicit Enrichment of Public Officials: A Model draft that respects Human Rights in Corruption Cases, Volume 45, No. 1, Journal of Crime, Law and Social Change, Publisher Springer Netherlands, pp. 27-53.

[38] Attorney General v. Hui Kin-Hong, [1995] 1H.K.C.L.R227(C.A.).

[39] Attorney General v. Hui Kin-Hong, Court of Appeal No. 52 of [1995]. 
[40] Interview with Abera Abadi, Head of the Corruption Crimes Investigation Directorate at FPC, Done at his Office, 21 August, 2019.

[41] Interview with BogaleTaso, Senior Declaration Officer and Team leaders of Assets Disclosure and Registration Directorate at the FEACC, Done at his Office, 7June, 2019.

[42] Federal Ethics and Anti-Corruption Commission, Assets Disclosure and Registration Form, April, 2010 E. C.
[43] Persson A. (2013). Why Anticorruption Reforms Fails Systemic Corruption as a Collective Action Problem, 26(3), Governance, p. 454.

[44] Snider TR and Kidane. (2007). Combating Corruption through International Law in Africa: A Comparative Analysis, 40 Cornell International Law Journals, p. 695. 